\title{
EFFECT OF NATURAL LIGHTING, COMBINATION OF SOAKING AND IRRIGATION, AND SEEDING RATE ON BARLEY GREEN FODDER PRODUCTION UNDER FARMER'S DOMESTIC ROOM CONDITIONS
}

Hussien A. Elsoury ${ }^{1}$, Abdulwahed M. Aboukarima ${ }^{2}$ and Magdy I. Bayomi ${ }^{3}$

\section{ABSTRACT}

The increasing competition between animal fodder and human food on the limited cropping in Egypt led to increasing prices of raw materials which are used in manufacturing fodder. On the other hand, there is an alternative method that can be used to produce low-cost fodder with fewer efforts, without any electric energy and with lower water consumption. This study was carried out to evaluate the sprouting process of barley grains under farmer's domestic room conditions. Effect of natural lighting, combination of soaking and irrigation and seeding rate $\left(4.01,5.50\right.$ and $\left.6.47 \mathrm{~kg} / \mathrm{m}^{2}\right)$ on the investigated variables (green fodder yield, plant height and conversion factor of seeds into green fodder) were studied. Average values of temperature, relative humidity and lighting intensity in the farmer's domestic room with natural illumination were $28.0^{\circ} \mathrm{C}, 72.8 \%$ and 147 lux, respectively. Meanwhile, average values of temperature, relative humidity and lighting intensity in the farmer's domestic room without natural illumination (dark room) were $27.7^{\circ} \mathrm{C}$, $73.8 \%$ and 0 lux, respectively. The average dimensions of the used barley grains were $9.8 \mathrm{~mm}$ length, 3.4 width and $2.7 \mathrm{~mm}$ thickness. The average final bulk density and weight of 1000 seeds of barley grains were 0.590 $\mathrm{g} / \mathrm{cm} 3$ and $40.85 \mathrm{~g}$, respectively. The average initial moisture content (dry basis) of the barley grains was $13.95 \%$. The results of this study showed that the conversion factor was about 5.81 times per $\mathrm{kg}$ of barley grains. The combination of soaking and irrigation and natural lighting treatments had significant effect $(p \leq 0.05)$ on green fodder yield.

\footnotetext{
${ }^{1}$ Researcher, Agric. Eng. Res. Inst., Agric. Res. Centre, Egypt.

${ }^{2}$ Senior Res., Agric. Eng. Res. Inst., Agric. Res. Centre, Egypt.

${ }^{3}$ Head of Research, Agric. Eng. Res. Inst., Agric. Res. Centre, Egypt.
} 
In conclusion, local barley cultivar has an ability to produce green fodder under farmer's domestic room conditions with less water consumption; and no energy and no special equipment. These findings are considered very important as the framers could use any domestic room in their houses to produce green fodder using barley seeds which are mostly available in the local market in Egypt at low price.

\section{INTRODUCTION}

$\mathrm{F}$ lodder or fresh forage is used specifically to feed livestock such as cattle, sheep, horses and chickens. Under Egyptian conditions where soil, water and energy are the main limiting factors for agricultural production, it is preferable to seek to develop planting systems to enable the production of fresh forage from barley, wheat and other grains. All these efforts must be done to be carried out in this field to overcome the shortage of soil, irrigation water and energy. These efforts were focusing on simple techniques to cultivate seeds without soil while providing the plant requirements. Fortunately, the concept of putting one kilogram of grain into a hydroponic system and producing 6 to 10 kilograms of fresh green sprouts, independent of weather and at any time of the year, is of interest to solve the shortage problem of fodder (Kruglyakov, 1989). Furthermore, forage grains could be germinated and grown for short period of time inside special growing rooms, provided with the appropriate growing conditions to produce fresh forage (Sneath and McIntosh, 2003).

Producing sprouts involves soaking the grain, most commonly barley, in water until fully saturated, followed by draining and placing it in trays or troughs for sprouting, usually for 5 to 8 days. The grain is kept moist during this period. Soaking is important as there is a rapid uptake of water which facilitates the metabolism of reserve material and the utilisation of these reserves for growth and development (Thomas and Reddy, 1962). However, grain is often soaked or washed with a sterilising solution to help minimise the risk of mould. The yield and quality of produced sprouts are influenced by many factors such as soaking time, grain quality, grain variety and treatments, temperature, humidity, nutrient supply, depth and density of grain in troughs and the incidence of mould (Bull and Peterson, 1969; Trubey et al., 1969). To achieve maximum 
yield and nutritional benefits of sprouts, the grain should be clean, sound, free from broken or infested seeds and untreated and viable (Thomas and Reddy, 1962).

Barley (Hordium vulgare L.) is a popular fodder with good adaptability to wide range of climate and soil (Al-Ajmi et al., 2009) and it is a major cereal grain, a member of the grass family. It serves as a major animal fodder (El-Mouhamady et al., 2012). In Egypt, barley is mostly used for animal feed and rarely in human food, with approximately $20 \%$ being used for malting purposes (Hussein et al., 2004). On the other hand, sprouting activities in the seeds have many changes, the protein is converted to essential amino acids, carbohydrates are converted to sugars and fats are converted to essential fatty acids (Chavan and Kadam, 1989). However, sprouts are much easier to be digested than dry seeds (Goodwin and Mercer, 1993) where nutrient proportions of sprouted barley are changed by the growing cycle (Cuddeford, 1989). Besides, in germinated grains, obvious increasing in protein, fat, ash, crude fibre and decrease in dry matter and carbohydrate content was noted (Abbas, 2009).

Chung et al. (1989) found that the fibre content increased from 3.75\% in un-sprouted barley seed to $6 \%$ in 5-day sprouts. Comparing of green sprouted with no-sprouted barley shown that the total amount of protein remained similar, though the percentage of protein increased in green fodder because of the decrease in other components (Peer and Leeson, 1985b; Morgan et al., 1992).

Grain sprouting process on site can be a dependable and low cost source of fresh forage creating a local, on demand feed source. However, commercial sprouts groweres have reported fresh weight increaseses of bewteen 6 an 10 fold (i.e, $1 \mathrm{~kg}$ of seed yielding about 6-10 $\mathrm{kg}$ of fresh sprouts) while trial yields from experiments indicated a 5-8 fold increase in fresh wieght with sprouting of garin (Sneath and McIntosh, 2003). Depending to the type of grain, the forage mat could reach between 15 to $30 \mathrm{~cm}$ high at the production rate about 7 to $9 \mathrm{~kg}$ of fresh forage (Al-Ajmi et al., 2009). The period between starting the production and green forage harvesting was about one week where a carpet is obtained made up of 
germinated seeds, their interweaved white roots and the green shoots (EIDeeba et al., 2009).

Al Ajmi et al. (2009) conducted a laboratory experiment to evaluate yield of barley fodder irrigated with tertiary treated sewage effluent (TTSE) under hydroponic system. Barley seeds of a commercial grade with good viability (80-85\%) were sterilized with $20 \%$ sodium hypochlorite solution to control fungal growth. Seeds were sown in stacked trays in a temperature controlled farmer room. Trays were irrigated daily with either tap water (T1), or tap water mixed with TTSE at $20 \%, 40 \%, 60 \%, 80 \%$ (T2 to T5) and with TTSE only (T6). Eighty grams of seeds were sown per tray (dimensions $40 \mathrm{~cm} \times 43 \mathrm{~cm} \times 6 \mathrm{~cm}$ ). This is equivalent to seed rate of $4.65 \mathrm{~kg} / \mathrm{m}^{2}$. The trays were covered with plastic cover to prevent seed drying. Plants were harvested 9 days after sowing. Green fodder weight was recorded. The results showed average green forage yield ranged from less than 90 tones/ha with tap water to around 130 ton/ha with TTSE (T6). This increase in yield may be attributed to the high nitrogen content in TTSE.

El-Deeba et al. (2009) established a closed hydroponic unit for intensive grass fodder production. The unit frame was constructed from aluminium angles with a length of $125 \mathrm{~cm}$, a width of $36 \mathrm{~cm}$ and a height of $48 \mathrm{~cm}$. The unit was covered with $0.4 \mathrm{~cm}$ thick plastic sheets. The plant growth unit consisted of trays. Each tray was made of foam with dimensions of $30 \times 30 \times 4 \mathrm{~cm}$. The aim of their study was to investigate different parameters affecting the efficiency of the suggested unit. These parameters included light intensity, duration of aeration and applied amounts of water. The suggested unit included lighting system to provide plants with its lighting requirement, cooling and air conditioning unit to conserve the appropriate microclimate conditional to propagate a healthy plants and equipment, aeration and $\mathrm{CO}_{2}$ proportioning system, to enhance the root-zone media with its air balance and requirements to avoid the plant stress. The studied treatments of the affecting parameters were lighting time $(8,12,16$ and $24 \mathrm{~h}$ /day) with a fixed intensity of about 2000 lux, aeration $(2,3,5 \mathrm{~min} / 2 \mathrm{~h})$ and irrigation period $(1,2$ and $3 \mathrm{~min} / 2 \mathrm{~h}$ ). The barley seeds (Giza, 124), were used. The seeds were soaked for 24 
hours and transferred to the unit where the growing period was for 8 days. The results showed that maximum fodder production was to be $1500 \mathrm{~g}$.

Fazaeli et al. (2012) built a hydroponic system and grain sprouting using a steel hydroponic chamber, size of $4.0 \times 3.0 \times 2.6 \mathrm{~m}$ equipped with automatic sprayer irrigation and ventilation apparatus with capacity of 100 polyethylene trays sized $70 \times 30 \mathrm{~cm}$ each. Temperature inside the chamber was controlled to get a range of working temperature from $18^{\circ} \mathrm{C}$ to $21^{\circ} \mathrm{C}$ and the relative humidity adjusted about $70 \%$ using an air circulation. Fluorescent lighting tubes with watertight appliances were arranged on the walls in vertical position to growing leaves when it provides 1000 to 1500 microwatts $/ \mathrm{cm}^{2}$ during 12 to $14 \mathrm{~h}$ of daily light. Clean seeds of barley were washed and soaked in tap water for $20 \mathrm{~h}$ then were spread in the trays, where the density obtained was equivalent to seed rate of $4.5 \mathrm{~kg} / \mathrm{m}^{2}$. Three growth periods: 6,7 and 8 days were considered. The results showed that during the growing cycle of sprouting barley, the main visible change was the increase in root length and thickness and the average green forage yield ranged from $4.93 \mathrm{~kg}$ per $\mathrm{kg}$ of barley grain at day 6 to $7.21 \mathrm{~kg}$ at day 8 .

Fayed (2011) used tray method for seed sprouts to produce green forage from barley grains. About $10 \mathrm{~cm}$ thick layer of chopped rice straw (Rs) or Tamarix maniform (Tm) were used as a sprouting media. Barley grains were washed and soaked in tap water and stored in a dark area for $12 \mathrm{hr}$. (overnight) to allow for initial germination. At the end of soaking period soaked seeds were spread evenly on the top of Tamarix (Tm) or Rs media. Germination period on the media surface lasted about 10 days to get shoot sprouts. Barley seeds were used at $20 \%$ density of roughage (rice straw and Tamarix). The shoot length was $10-15 \mathrm{~cm}$ from this experiment.

Dung et al. (2010) used a hydroponic unit to sprout barley in a temperature controlled room. The temperature was maintained at $25^{\circ} \mathrm{C}$ and continues lighting was also provided throughout the 7 days sprouting period. Three pairs of fluorescent lamps were used. Theses lamps provided an average light intensity of about 615 lux. The measurement of light intensity was done at the surface of the sprouted material. Spray watering was applied for $3 \mathrm{~min}$ in every $2 \mathrm{~h}$ for the 7 days period of 
sprouting. A sprinkler with a timer control device was used. Barley seeds were steeped in warm water containing $0.1 \%(\mathrm{v} / \mathrm{v})$ hypochlorite at $24{ }^{\circ} \mathrm{C}$ for $4 \mathrm{~h}$ before they were transferred to perforated trays for watering. The steeped seeds were placed in plastic trays at a rate of 6.7 $\mathrm{kg} / \mathrm{m}^{2}$ (100 g / tray). Thirty plastic trays measuring $10 / 15 \mathrm{~cm}$ each $(0.15$ $\mathrm{m}^{2}$ ) were used. The results showed that fresh sprouts weighed were about 3.7 times their original pre-steeped weight after 7 days.

Al-Karaki (2011) utilized a hydroponic system which was composed of two cabinets (units) with metal frame and four shelves each with a length of $200 \mathrm{~cm}$, a width of $55 \mathrm{~cm}$, and a height of $240 \mathrm{~cm}$ to produce approximately $80-100 \mathrm{~kg}$ green fodder per growth cycle (9 days). Each unit of the system could carry 28 planting trays. The horizontal area occupied by each unit of the system was about $2 \mathrm{~m}^{2}$ including the walkway between neighbouring units. Polystyrene trays with a length of $45 \mathrm{~cm}$, a width of $25 \mathrm{~cm}$ and a depth of $8 \mathrm{~cm}$ were used for growing seeds to produce green fodder. An air conditioning unit was used to control temperature inside the growth room which was maintained at $24 \pm 2^{\circ} \mathrm{C}$. The relative humidity in the growth room ranged between 50 and $73 \%$. Seeds of barley were cleaned from debris and other foreign materials. Then the cleaned seeds were surface sterilized by soaking for 30 minutes in a $20 \%$ sodium hypochlorite solution (Clorox bleach) to prevent the formation of mould. Planting trays and the growing cabinet also were cleaned and disinfected. The seeds were washed well from residues of bleach and re-soaked in tap water overnight (about 12 hours) before sowing. Seeds were sown in the polystyrene trays lined with black plastic sheets and have holes at the bottom to allow drainage of excess water from irrigation. The seeding rate used in this experiment was about 450 $\mathrm{g} /$ tray (equivalent to about $4.0 \mathrm{~kg} / \mathrm{m}^{2}$ ). Trays were irrigated daily with three water types: tertiary sewage treated wastewater (WW), tap water (TW), and mixture of equal amounts of WW and TW (WW mix). Planting trays were irrigated twice a day from each water type (early in the morning and late in the afternoon) to provide enough water to keep the seeds / seedlings moist. The results indicated significant differences among various water treatments used in this study were found in green and dry biomass traits. Higher yields of fresh green and dry matter were 
recorded in plants irrigated with WW than for TW. Average green forage yield ranged from 224 ton/ha with tap water to around 320 ton/ha with WW for one production cycle ( 9 days).

Lighting may be an effective tool for photochemical-rich vegetable cultivation (Urbonavičiūtė et al., 2009). However, some light in the second half of the sprouting period encourages photosynthesis and greening of the sprouts. If the seedlings are grown without light or too low a light intensity, photosynthesis is non-existent or minimal (Peer and Leeson, 1985a). Besides hydroponic fodder production is a well-known technique for high fodder yield, year round production and least water consumption (Cuddeford, 1989; Al-Karaki, 2008). Meanwhile, AlKaraki (2010) reported that about 1.5-2 litres are needed to produce $1 \mathrm{~kg}$ of green fodder hydroponically in comparison to 73.5, 85.5, and 167 litres to produce $1 \mathrm{~kg}$ of green fodder of forage barley, alfalfa, and Rhodes grass under field conditions. Furthermore, hydroponic technique is one of the future solutions of the shortage in the green fodder (Adel Eshtayeh, 2004) and it is recommended to local farmers to use such technique as an alternative fodder not only for sheep but also for all different types of livestock. Moreover, economical performance of hydroponic green forage production and utilization depends on the local conditions where it is need to be identified (Fazaeli et al., 2012) and also growing forage hydroponically is now becoming popular to produce green fodders in large quantities with less water use (Al-Karaki and Al-Hashimi, 2012). Besides the limitation of water and energy requirements for agricultural production in Egypt, so this work was carried out to evaluate a simple system for growing barely seeds to produce green fodder. The system was laid in a conventional room without temperature controlling. Influences of lighting, combination of soaking and irrigation of grains and grain seeding rate on barley green fodder production were investigated.

\section{MATERIALS AND METHODS}

\section{Experimental site}

The experiment was conducted during July 2014 at Tractors and Farm machinery Testing \& Research Station at Sabahia Alexandria Governorate, Egypt. This location lies between latitude $30.76^{\circ}$ north and longitude $29.696^{\circ}$ east. Simple wood shelves (Figure 1) having 
dimensions of $50 \mathrm{~cm} \times 110 \mathrm{~cm}$, just to carry the sprouting trays, were fabricated from a plain wood of cross section of " $1 x^{\prime \prime} 2$. The used shelves were placed in the farmer's domestic room one meter height above the ground. The horizontal distance between the shelves and the room window was about $1 \mathrm{~m}$. The plastic trays had the dimensions of $150 \mathrm{~mm}$ length $\times 103 \mathrm{~mm}$ width $\times 50 \mathrm{~mm}$ height were used for sprouting grains. The trays have a drainage holes at the bottom to allow drainage of excess water due to irrigation.

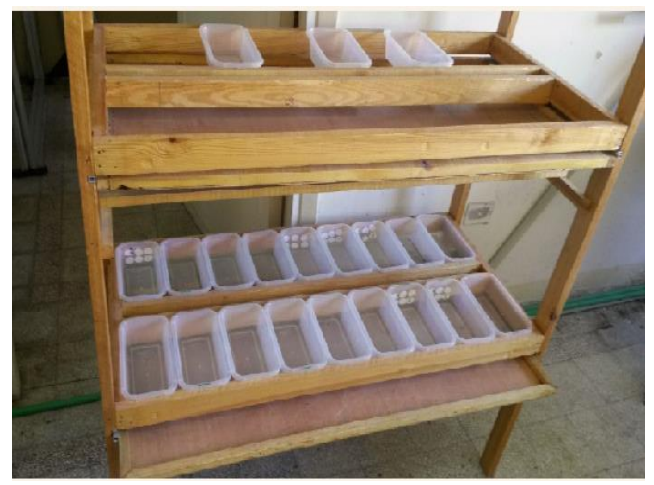

Figure (1). Simple wooden shelves occupied with plastic trays.

\section{Procedures of sowing barley seeds}

Barley seeds were Giza 126 of good viability (87-92\%) were obtained from Ministry of Agriculture, Alexandria seed station, Egypt. The following steps were undertaken to execute the sprouting experiments:

- Barley seeds were cleaned manually from any foreign seeds or strange materials as possible.

- Barley seed dimensions were measured by Digital Vernier calliper.

- Digital balance was used to weight 1000 seeds of barley.

- Bulk density of barley seeds was determined according to the method defined by Mohsenin (1980) and Singh and Goswami (1996).

- Moisture content of barley seeds was determined using hot air ovens according to ASAE standards (ASAE, 1982) based on dry basis, however the dry basis moisture content (d.b.) is defined as the ratio of the water weight to the dried weight of the kernels (Chen, 2003).

- The barley seeds surface was cleaned and sterilized by soaking them in a sodium hypochlorite solution $0.02 \%$ (Clorox bleach) for 10 minutes to prevent the formation of mould. 
- Sprouting trays were cleaned and disinfected by washing them in a sodium hypochlorite solution $0.02 \%$ (Clorox bleach). Barley seeds and sprouting trays were washed well from residues of bleach.

- Barley seeds were soaked in water for about 12 hours then the seeds were removed from water and spread onto plastic sheet for about 1 hour. The seeds were then soaked in water for another 12 hours (before sowing).

- Soaked barley seeds were evenly spread on the plastic trays. However, they were placed inside the trays at different seeding rates (seed rate was determined by divided seed weight on area of the tray $(0.01545$ $\left.\mathrm{m}^{2}\right)$ ) with units of $\mathrm{kg} / \mathrm{m}^{2}$.

\section{Treatments under investigation}

- The first treatment was the seeding rate. This treatment has three levels $\left(62 \mathrm{~g} /\right.$ tray $\left(4.01 \mathrm{~kg} / \mathrm{m}^{2}\right), 85 \mathrm{~g} /$ tray $\left(5.50 \mathrm{~kg} / \mathrm{m}^{2}\right)$ and $100 \mathrm{~g} /$ tray $(6.47$ $\left.\left.\mathrm{kg} / \mathrm{m}^{2}\right)\right)$.

- The second treatment has two levels. The first level was combination of soaking barley seeds in tap water and the irrigation system was carried out by using tap water. The second level was combination of soaking barley seeds in tap water and the irrigation system was carried out using nutrition solution with water. One litre of the nutrition solution was dissolved in 10 litres tap water. The commercial name of the nutrition solution is ENHANCER (Agrico Company) and its specifications of compositions are given in Table (1).

- The third treatment was sprouting process in different farmer's domestic rooms. The first farmer's domestic room has a window (1 meter height and 1 meter width) to be utilized as a natural illumination with no artificial lights. A wire mesh frame was fixed on the room window. The second farmer's domestic room has a closed window during the experiment, so no natural illumination was provided (dark room). The natural light intensity was measured using the light meter UK-10LX, made in Taiwan (Figure 2). The relative humidity and temperature inside the farmer's domestic rooms were measured with a commercial setup.

- All experiments were conducted under farmer's domestic room conditions (i.e. no temperature controlling, no aeration system, etc). 
Table (1). The specifications of compositions of the nutrition solution (ENHANCER).

\begin{tabular}{|l|c|c|}
\hline \multicolumn{1}{|c|}{ Components } & Chemical symbol & Percentage (\%) \\
\hline Total Nitrogen & $\mathrm{N}$ & 15 \\
\hline Phosphorate & $\mathrm{P}_{2} \mathrm{O}_{5}$ & 5 \\
\hline Potassium & $\mathrm{K}_{2} \mathrm{O}$ & 2 \\
\hline Zinc & $\mathrm{Zn}$ & 2 \\
\hline Iron & $\mathrm{Fe}$ & 1 \\
\hline Manganese & $\mathrm{Mn}$ & 4 \\
\hline Sulphate & $\mathrm{SO}_{4}$ & 4.5 \\
\hline Cupper & $\mathrm{CU}$ & 1 \\
\hline
\end{tabular}

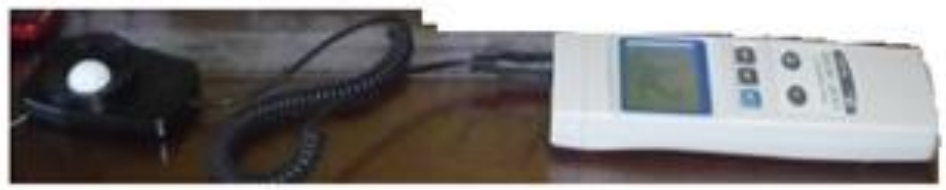

\section{Figure (2).The set up for measuring natural light intensity.}

The trays were stacked on shelves in a randomized complete block design with three replicates. Trays were irrigated daily with the specified solution 4 times a day by a manual atomizer, (early in the morning and in the afternoon, late afternoon, and in the night). The amount of tap water was $428 \mathrm{~cm}^{3}$ for each treatment. The experiment was terminated after 8 days from sowing the seeds by harvesting the plants. Table (2) presents symbols and name of the treatments under investigation and the treatments symbols are listed in Table (3).

Table (2). Symbols of the treatments under investigation.

\begin{tabular}{|c|c|c|c|c|c|}
\hline $\begin{array}{l}\text { Seeding } \\
\text { rate } \\
\left(\mathrm{kg} / \mathrm{m}^{2}\right)\end{array}$ & Symbol & $\begin{array}{c}\text { Combination of soaking } \\
\text { and irrigation }\end{array}$ & Symbol & $\begin{array}{c}\text { Farmer's } \\
\text { domestic room } \\
\text { illumination }\end{array}$ & Symbol \\
\hline 4.01 & L1 & $\begin{array}{c}\text { Soaked seeds in tap } \\
\text { water and irrigation was } \\
\text { carried out using tap } \\
\text { water }\end{array}$ & I1 & $\begin{array}{l}\text { Natural } \\
\text { illumination }\end{array}$ & G1 \\
\hline 5.50 & L2 & \multirow[t]{2}{*}{$\begin{array}{l}\text { Soaked seeds in tap } \\
\text { water and the irrigation } \\
\text { was carried out using } \\
\text { nutrition solution }\end{array}$} & \multirow[t]{2}{*}{ I2 } & \multirow[t]{2}{*}{ Light absence } & \multirow[t]{2}{*}{ G2 } \\
\hline 6.47 & L3 & & & & \\
\hline
\end{tabular}


Green fodder yield and plant height were measured and conversion factor was calculated. However, the production conversion ratio, based on the amount of fresh fodder produced per unit of seed used, could be used for comparing the investigated treatments and with other pervious works. However the production conversion ratio could be affected by several factors such as type of grain, variety, management factors, irrigation, nutrients solution, temperature, humidity, lights, density of seeds on each tray and the number of growing days (Bull and Peterson, 1969; Trubey et al., 1969). It gives indication about the success of the sprouted process.

\section{Statistical analysis}

The data for the plant height, the green fodder weight and the conversion factor were statistically analysed using three-way analysis of variance (ANOVA) for the randomized complete design with three replicates.

Tale (3). Symbols of the investigated treatments combinations.

\begin{tabular}{|c|c|c|c|}
\hline $\begin{array}{c}\text { Treatment } \\
\text { symbol }\end{array}$ & $\begin{array}{c}\text { Combination of } \\
\text { soaking and } \\
\text { irrigation }\end{array}$ & $\begin{array}{c}\text { Farmer's } \\
\text { domestic room } \\
\text { illumination }\end{array}$ & $\begin{array}{c}\text { Seeding } \\
\text { rate }\end{array}$ \\
\hline T1 & I1 & G2 & L3 \\
\hline T2 & I2 & G2 & L2 \\
\hline T3 & I2 & G2 & L3 \\
\hline T4 & I1 & G1 & L1 \\
\hline T5 & I2 & G1 & L1 \\
\hline T6 & I1 & G2 & L1 \\
\hline T7 & I1 & G2 & L1 \\
\hline T8 & I2 & G2 & L2 \\
\hline T9 & I1 & G1 & L3 \\
\hline T10 & I1 & G1 & L2 \\
\hline T11 & I2 & G1 & L3 \\
\hline T12 & I2 & & \\
\hline
\end{tabular}


The used software was SAS (1998) using ANOVA procedure. Comparisons among treatment means, when significant, were conducted using least significant difference (LSD) at $\mathrm{p}=0.05$ level.

\section{RESULTS AND DISCUSSION}

\section{Physical properties of barley grain}

The average dimensions of the used barley grains were $9.76 \mathrm{~mm}$ length, 3.36 width and $2.69 \mathrm{~mm}$ thickness. The average final bulk density and weight of 1000 seeds of barley grains were $0.590 \mathrm{~g} / \mathrm{cm}^{3}$ and $40.85 \mathrm{~g}$, respectively. The average initial moisture content of the barley grains was $13.95 \%$ d.b. Figure (3) illustrates the barley green fodder yield pictorial under growing in two farmer's domestic rooms. It is clear from Figure (3) that under natural illumination, the sprouts are healthy compared to the sprouts under light absence.

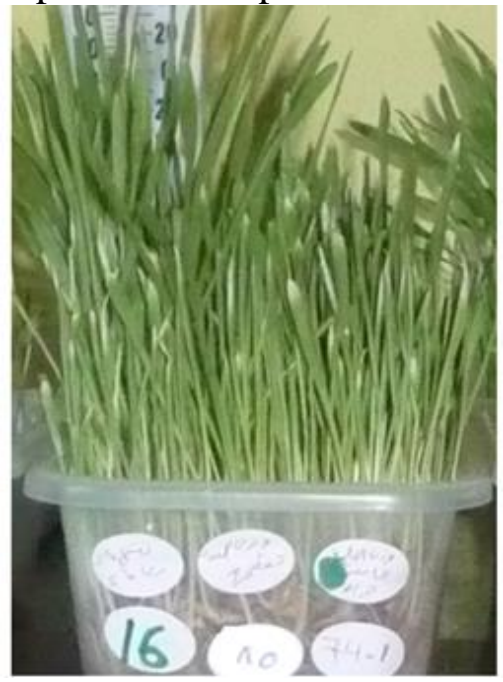

Natural illumination (G1)

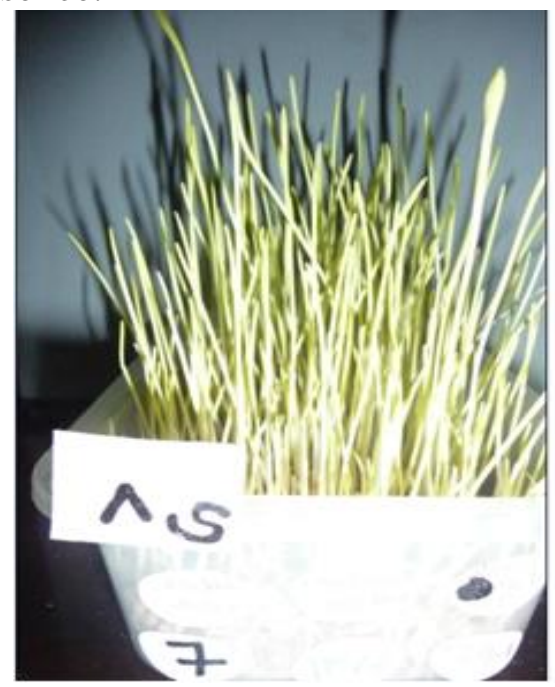

Light absence (G2)

Figure (3). Barley green fodder yields in natural illumination and in light absence condition.

\section{Analysis of ambient conditions}

Figure (4) illustrates variations of averages of ambient temperature and relative humidity with experiment days in two farmer's domestic rooms (natural illumination and light absence). However starting day was on 29/6/2014 and ending day was 6/7/2014. Overall averages of temperatures and relative humidities in the farmer's domestic rooms with 
natural illumination were $28.01{ }^{\circ} \mathrm{C}$ and $72.81 \%$, respectively. Overall averages of temperature and relative humidities in the farmer's domestic room without natural or artificial illumination (dark room) were $27.66{ }^{\circ} \mathrm{C}$ and $73.78 \%$, respectively.


Figure (4).Variations of averages of ambient temperature and relative humidity with experiment days in two farmer's domestic rooms (natural illumination (G1) and light absence (G2)).

Figure (5) shows light intensity versus time of the sixth day (4/7/2014) of the experiment. Meanwhile, Figure (6) illustrates variations of average of light intensity with experiment days. Average of lighting intensity in the room with natural illumination was 147 lux.



Figure (5). Light intensity versus time of the sixth day $(4 / 7 / 2014)$ of the experiment. 


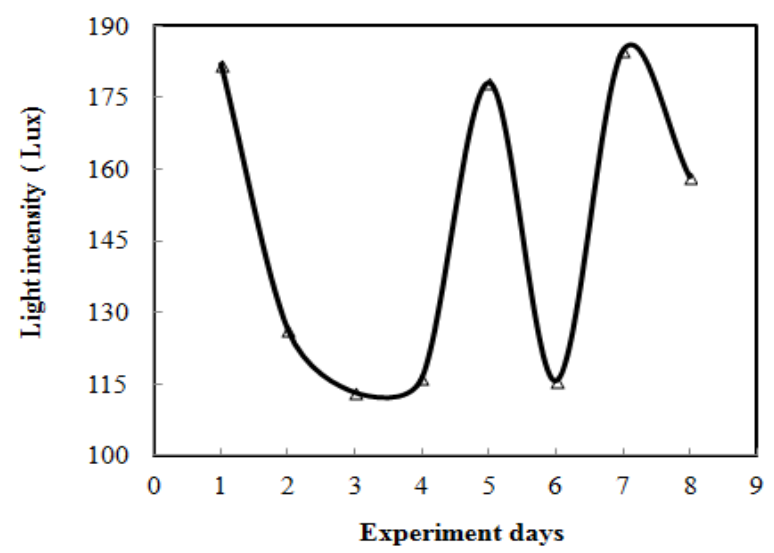

Figure (6).Variations of averages of light intensity with experiment days.

\section{Statistical analysis of investigated variables}

Combination of soaking and irrigation (I) and seeding rate (L) treatments and $\mathrm{I} \times \mathrm{L}$ interactions provided significant response for green fodder yield (Table 4). This significant indicate obvious impact of different combination of soaking and irrigation and seeding rate levels on green fodder yield. In addition, highly significant variations were estimated between combination of soaking and irrigation and seeding rate treatments on conversion factor and also $\mathrm{I} \times \mathrm{L}$ interactions had significant effect on conversion factor. Meanwhile, natural lighting $(\mathrm{G})$ treatment and I $\times G$ interactions provided obvious significant response for the plant height.

Table (4). Probabilities of significance for different parameters as affected by natural lighting $(\mathrm{G})$, combination of soaking and irrigation (I) and seeding rate (L).

\begin{tabular}{|c|c|c|c|c|c|c|c|}
\hline Parameters & $\mathrm{I}$ & $\mathrm{G}$ & $\mathrm{L}$ & $\mathrm{I} \times \mathrm{G}$ & $\mathrm{I} \times \mathrm{L}$ & $\mathrm{G} \times \mathrm{L}$ & $\mathrm{I} \times \mathrm{G} \times \mathrm{L}$ \\
\hline $\begin{array}{c}\text { Green fodder } \\
\text { yield }\end{array}$ & $* *$ & $\mathrm{Ns}$ & $* *$ & $\mathrm{Ns}$ & $* *$ & $\mathrm{Ns}$ & $\mathrm{Ns}$ \\
\hline $\begin{array}{c}\text { Conversion } \\
\text { factor }\end{array}$ & $* *$ & $\mathrm{Ns}$ & $* *$ & $\mathrm{Ns}$ & $* *$ & $\mathrm{Ns}$ & $\mathrm{Ns}$ \\
\hline Plant height & $* *$ & $* *$ & $* *$ & $* *$ & $\mathrm{Ns}$ & $\mathrm{Ns}$ & $\mathrm{Ns}$ \\
\hline
\end{tabular}

$* *$ and $*$ are significant at $\mathbf{p}<0.01$ and $\mathbf{p}<0.05$, respectively. Ns: not significant.

Table (5) lists mean conversion factor, green fodder yield and plant height as affected by combination of soaking and irrigation treatment. It is 
obvious that, there is significant effect of combination of soaking and irrigation treatment on conversion factor, green fodder yield and plant height. However, the soaked seeds in tap water and the irrigation was carried out using nutrition solution treatment (I2) gave higher seeding conversion factor, green fodder yield and plant height.

Table (5). Mean ${ }^{*}$ conversion factor, green fodder yield and plant height as affected by combination of soaking and irrigation treatment.

\begin{tabular}{|c|c|c|c|}
\hline $\begin{array}{c}\text { Soaking and } \\
\text { irrigation }\end{array}$ & $\begin{array}{c}\text { Mean conversion } \\
\text { factor (---) }\end{array}$ & $\begin{array}{c}\text { Mean green fodder } \\
\text { yield (tones/fed) }\end{array}$ & $\begin{array}{c}\text { Mean plant } \\
\text { height (mm) }\end{array}$ \\
\hline I2 & $6.76 \mathrm{a}$ & $147.14 \mathrm{a}$ & $157.95 \mathrm{a}$ \\
\hline I1 & $4.88 \mathrm{~b}$ & $106.55 \mathrm{~b}$ & $146.77 \mathrm{~b}$ \\
\hline LSD (5\%) & 0.24 & 4.80 & 6.49 \\
\hline
\end{tabular}

* Means followed by different letters in each column are significantly different at $\mathbf{P}=\mathbf{0 . 0 5}$. ** LSD = least significance difference.

Table (6) lists mean conversion factor, green fodder yield and plant height as affected by lighting treatment. It is obvious that, there is no significant effect of natural lighting treatment on conversion factor and green fodder yield but there is a significant effect of natural lighting on plant height. However, the plants in farmer's domestic room with natural illumination (G1) gave highest plant height.

Table (7) lists mean conversion factor, green fodder yield and plant height as affected by seeding rate treatment. It is obvious that, there is significant effect of seeding rate treatment on conversion factor, green fodder yield and plant height. However, the seeding rate of $85 \mathrm{~g} /$ tray gave the highest green fodder yield compared with other treatments.

Table (6). Mean ${ }^{*}$ conversion factor, green fodder yield and plant height as affected by lighting treatment.

\begin{tabular}{|c|c|c|c|}
\hline Lighting & $\begin{array}{c}\text { Mean conversion } \\
\text { factor (---) }\end{array}$ & $\begin{array}{c}\text { Mean green fodder } \\
\text { yield (tones/fed) }\end{array}$ & $\begin{array}{c}\text { Mean plant } \\
\text { height (mm) }\end{array}$ \\
\hline G1 & $5.87 \mathrm{a}$ & $127.74 \mathrm{a}$ & $173.20 \mathrm{a}$ \\
\hline G2 & $5.78 \mathrm{a}$ & $125.95 \mathrm{a}$ & $131.53 \mathrm{~b}$ \\
\hline LSD (5\%) & 0.24 & 4.80 & 6.49 \\
\hline
\end{tabular}

* Means followed by different letters in each column are significantly different at $\mathbf{P}=0.05$.

** LSD = least significance difference. 
Table (7). Mean* conversion factor, green fodder yield and plant height as affected by seeding rate.

\begin{tabular}{|c|c|c|c|}
\hline Seeding rate & $\begin{array}{c}\text { Mean conversion } \\
\text { factor (---) }\end{array}$ & $\begin{array}{c}\text { Mean green fodder } \\
\text { yield (tones/fed) }\end{array}$ & $\begin{array}{c}\text { Mean plant } \\
\text { height }(\mathrm{mm})\end{array}$ \\
\hline $62 \mathrm{~g} /$ tray & $6.53 \mathrm{a}$ & $109.74 \mathrm{c}$ & $149.35 \mathrm{a}$ \\
\hline $85 \mathrm{~g} /$ tray & $6.26 \mathrm{a}$ & $144.18 \mathrm{a}$ & $160.21 \mathrm{~b}$ \\
\hline $100 \mathrm{~g} /$ tray & $4.67 \mathrm{~b}$ & $126.62 \mathrm{~b}$ & $147.53 \mathrm{~b}$ \\
\hline LSD $(5 \%)^{* *}$ & 0.24 & 4.80 & 6.49 \\
\hline
\end{tabular}

* Means followed by different letters in each column are significantly different at $\mathbf{P}=\mathbf{0 . 0 5}$. ** LSD = least significance difference.

Figure (7) illustrates the variations values of average of green fodder yield with all treatments. It is clear that the treatment combination of soaked seeds in tap water and the irrigation was carried out using nutrition solution, $5.50 \mathrm{~kg} / \mathrm{m}^{2}$ seeding rate and natural illumination in farmer's domestic room was the best treatment and gave 159 tones/fed. Figure (8) illustrates the variations values of conversion factor with all treatments. It is clear that the treatment combination of soaked seeds in tap water and the irrigation was carried out using nutrition solution, $4.01 \mathrm{~kg} / \mathrm{m}^{2}$ seeding rate and natural illumination in farmer's domestic room was the best treatment. However, the mass production of fresh barely fodder was about 7.84 times per $\mathrm{kg}$ of barley grain for this treatment. The overall average of conversion factor for this study was 5.81 .

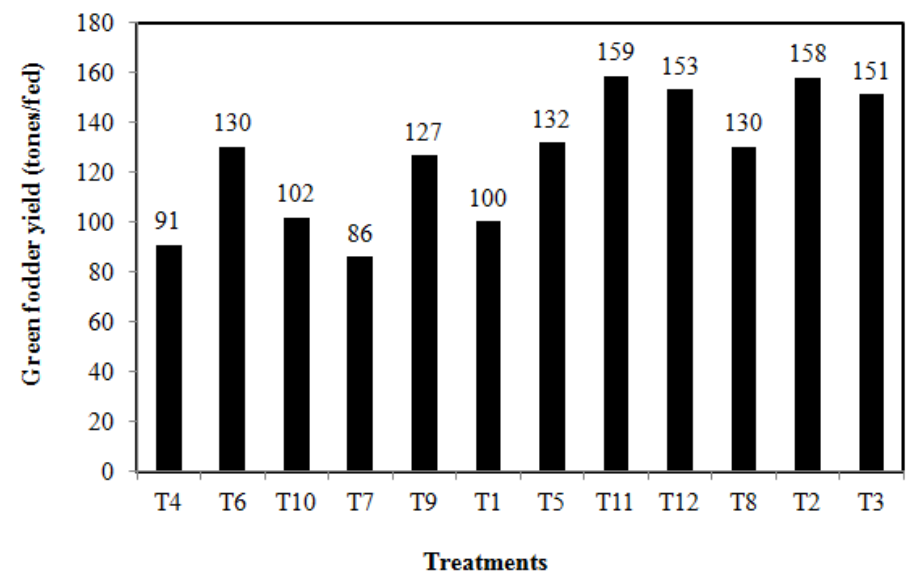

Figure (7).Variations values of average of green fodder yield with all treatments $\left(1 \mathrm{fed}=4200 \mathrm{~m}^{2}\right)$. 


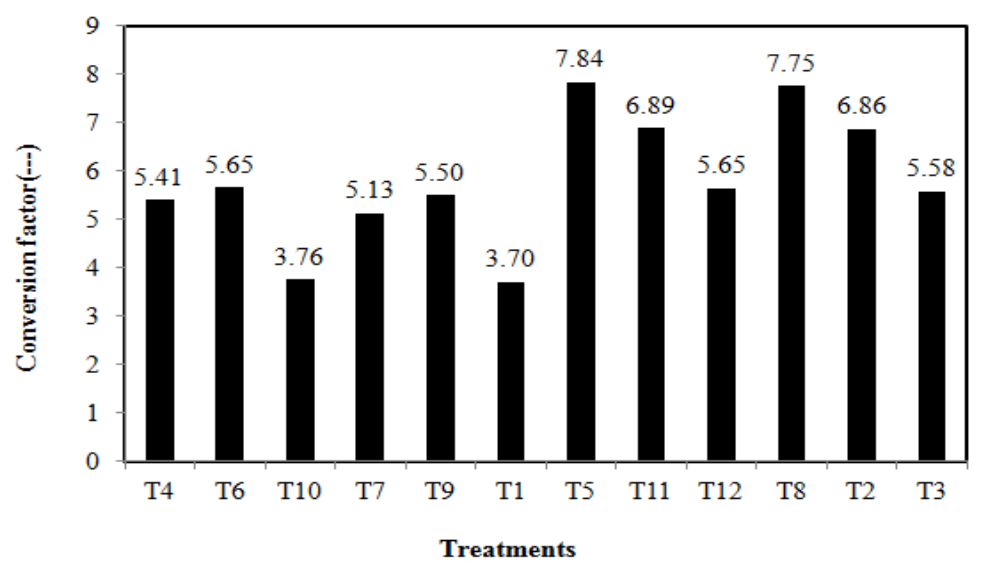

Figure (8).Variations values of average of conversion factor with all treatments.

Effect of seeding rate on averages of green fodder yield, conversion factor and plant height

Effect of seeding rate on averages of green fodder yield, conversion factor and plant height are presented in Figure (9), Figure (10) and Figure (11), respectively. Generally, green fodder yield at different combination of soaking and irrigation treatments increased polynomial when seeding rate increased from 4.01 to $5.50 \mathrm{~kg} / \mathrm{m}^{2}$ then decrease when seeding rate increased to $6.47 \mathrm{~kg} / \mathrm{m}^{2}$ as illustrated in Figure (9). This finding is agreed with the result of Sneath and McIntosh (2003), who sprouted barley with the equivalent of $2.5,5$ and $7.5 \mathrm{~kg} / \mathrm{m}^{2}$ of seed and were provided with nutrients at $500 \mu \mathrm{S}$ and irrigated and illuminated. Moreover, Massantini and Magnani (1980) reported forage weight increasing with seeding rates up to $5 \mathrm{~kg} / \mathrm{m}^{2}$.
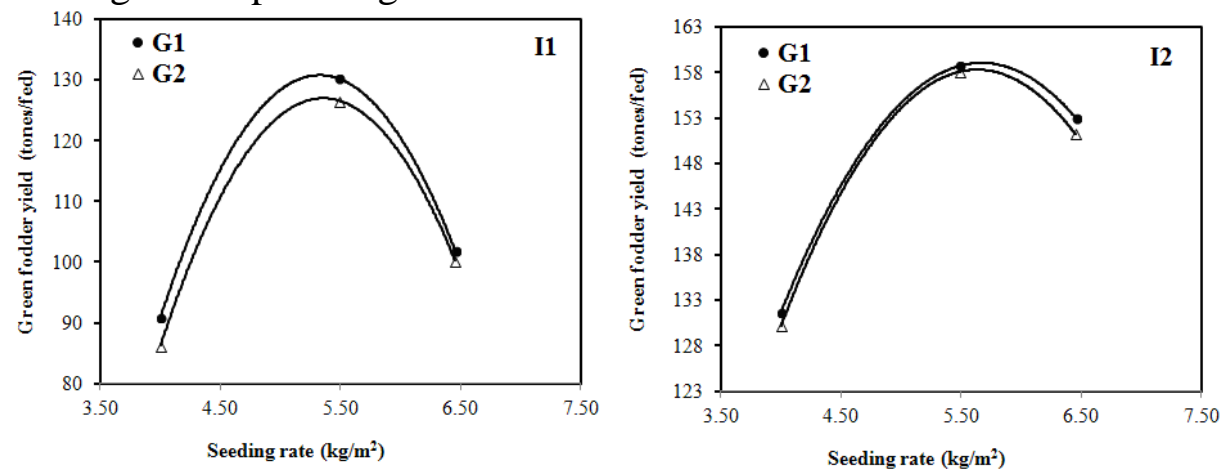

Figure (9). Effect of seeding rate on average of green fodder yield at different combination of soaking and irrigation treatments. 
Conversion factor is decreased as seeding rate increasing as illustrated in Figure (10). However, Peer and Leeson (1985a) reported that fresh weight increased 5.7-fold after 7 days during hydroponically sprouted barley grain in light, without nutrients, at $21^{\circ} \mathrm{C}$ and Fazaeli et al. (2011) reported that the mass production of fresh fodder was about 4.5 times per $\mathrm{kg}$ of barley grain and this was due to water absorption during germination and growth period. The production conversion ratio, based on the amount of fresh fodder produced per unit of the seed grain, ranged approximately 4 to 8 times (Peer and Lesson, 1985b; Morgan et al., 1992). Tudor et al. (2003) reports a yield increase of approximately 8 times where $9 \mathrm{~kg}$ of barley grain produced about $71.5 \mathrm{~kg}$ of sprouts in 6 days.
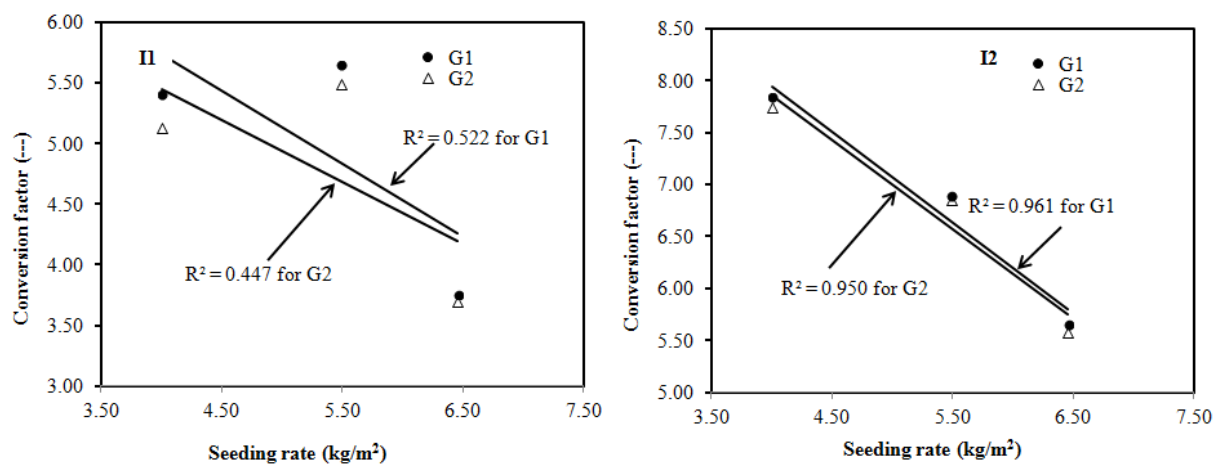

Figure (10). Effect of seeding rate on average of conversion factor at different combination of soaking and irrigation treatments.
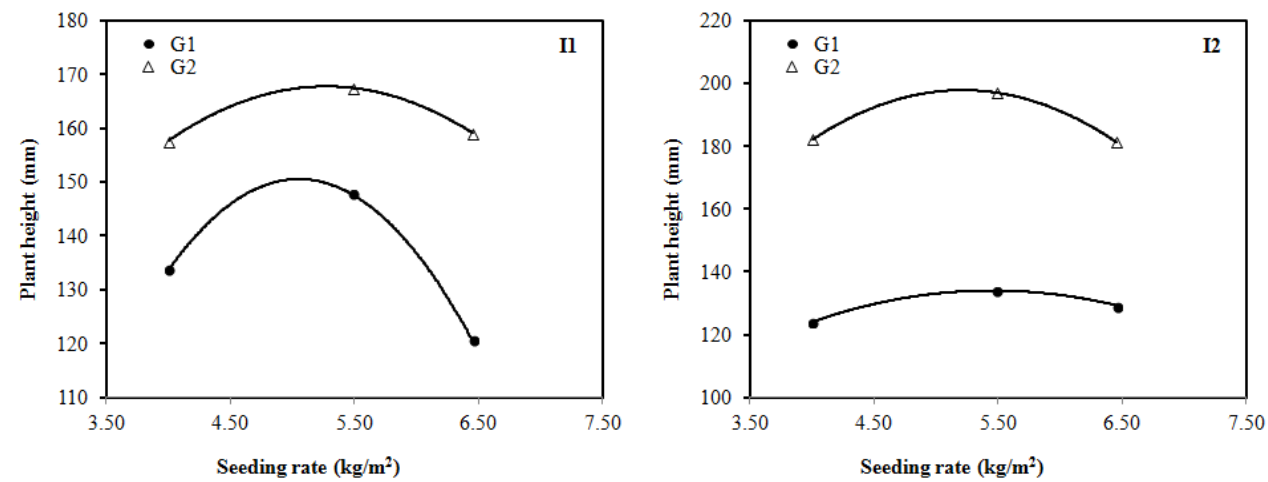

Figure (11). Effect of seeding rate on average of plant height at different combination of soaking and irrigation treatments. 
Plant height at different combination of soaking and irrigation treatments increased polynomial when seeding rate increased from 4.01 to 5.50 $\mathrm{kg} / \mathrm{m}^{2}$ then decrease when seeding rate increased to $6.47 \mathrm{~kg} / \mathrm{m}^{2}$ as illustrated to Figure (11). This result during barely sprouting may be due to overload of the seeds.

\section{CONCLUSION}

Farmer's domestic room conditions under simple treatments are providing a potential technique for green barley forage production. However, green barley forage yields obtained were ranged 86 to 159 tones/fed. Local barley cultivar has ability to produce green fodder under farmer's domestic room conditions with less water consumption; and no energy and no special equipment were required. These findings are considered very important as the framers could use any domestic room in their houses to execute such system using barley seeds which are mostly available in the local market at lower price.

\section{REFERENCES}

Abbas, T. A. A. (2009). Nutritional value of germinated wheat. AlMustansiriya J. Sci., 20(2):41-46.

Adel Eshtayeh, I. F. (2004). A new source of fresh green feed (hydroponic barley) for Awass sheep. Unpublished MSc. Theses in Environment Sciences, Faculty of Graduate Studies, at An- Najah National University, Nablus, Palestine.

Al-Ajmi, A., A. Salih, I. Kadhim and Y. Othman (2009). Yield and water use efficiency of barley fodder produced under hydroponic system in GCC countries using tertiary treated sewage effluents. Journal of Phytology, 1(5): 342-348.

Al-Karaki, G. N. and N. Al-Momani (2011). Evaluation of some barley cultivars for green fodder production and water use efficiency under hydroponic conditions. Jordan Journal of Agricultural Sciences, 7(3):448-457. 
Al-Karaki, G. N. (2008). Application of hydroponic culture in production of green fodder. Training workshop, Arabian Gulf University, Bahrain 21-23 April, 2008.

Al-Karaki, G. N. (2010). Hydroponic green fodder: alternative method for saving water in dry areas. Proceedings of the "Second Agricultural Meeting on Sustainable Improvement of Agricultural and Animal Production and Saving Water Use, September 2010, Sultanate of Oman.

Al-Karaki, G. N. (2011). Utilization of treated sewage wastewater for green forage production in a hydroponic system. Emir. J. Food Agric.,23 (1): 80-94.

Al-Karaki, G. N. and M. Al-Hashimi (2012). Green fodder production and water use efficiency of some forage crops under hydroponic conditions. ISRN Agronomy, Volume 2012, Article ID 924672, 5 pages.

Anonymous,http://seednet.gov.in/Material/Handbook_of_seed_testing/C hapter\%207.pdf

ASAE (1982). ASAE Standard (29th Edn.), S352_1. Moisture measurement-grain and seeds. St. Joseph, MI, USA.

Bull, R. C. and C. F. Peterson (1969). Nutritive value of sprouted wheat for swine and poultry. J. Anim. Sci., (Suppl.), 28(6): 856.

Chavan, J. and S.S. Kadam (1989). Nutritional improvement of cereals by sprouting. Critical Reviews in food science and Nutrition, 28: 401- 437.

Chen, C. (2003). Evaluation of air oven moisture content determination methods for rough rice. Biosystems Engineering,86 (4):447-457.

Chung, T., E.N. Nwokolo and J.S. Sim (1989). Compositional and digestibility changes in sprouted barley and canola seeds. Plant Foods for Human Nutrition, 39: 67-278. 
Cuddeford, D. (1989). Hydroponic grass. In Practice,11(5):211-214.

Dung, D.D., I.R. Godwin and J.V. Nolan (2010). Nutrient content in Sacco digestibility of barley grain and sprouted barley. Journal of Animal and Veterinary Advances, 9(19):2485-2492.

El-Deeba, M. M., M. N. El-Awady, M. M. Hegazi, F. A. Abdel-Azeem and M. M. El-Bourdiny (2009). Engineering factors affecting hydroponics grass- fodder production. The 16th. Annual Conference of the Misr Society of Ag. Eng., 25 July, 2009: 16471666.

El-Mouhamady, A. A., Kh. A. Amer and A.Y. Ragab (2012). Development of salinity tolerance in some genotypes of barley using line $\mathrm{x}$ tester analysis and some techniques of biotechnology. Journal of Applied Sciences Research, 8(2): 972-982.

Fayed, A. M. (2011). Comparative study and feed evaluation of sprouted barley grains on rice straw versus tamarix mannifera on performance of growing Barki lambs in Sinai. Journal of American Science, 7(1): 954-961.

Fazaeli, H., H. A. Golmohammadi, A. A. Shoayee, N. Montajebi and Sh. Mosharraf (2011). Performance of feedlot calves fed hydroponics fodder barley. J. Agr. Sci. Tech., 13: 367-375.

Fazaeli, H., H.A. Golmohammadi, S.N. Tabatabayee and M. Asghari-Tabrizi (2012). Productivity and nutritive value of barley green fodder yield in hydroponic system. World Applied Sciences Journal, 16 (4): 531-539.

Goodwin, T.W. and E. I. Mercer (1993). Introduction to plant biochemistry. Second edition copyright, Pergamum press Ltd.

Hussein, E.H.A., M. A. Madkour, S. K. Assem and A. M.A. Radwan (2004).Embryogenic callus formation and plant regeneration from immature embryos of some barley genotypes (Hordeum vulgare L.). Arab J. Biotech., 7 (1): 111-122. 
Kruglyakov, Yu. A. (1989). Construction of equipment for growing green fodder by a hydroponic technique. Traktory-I Sel'skokhozyaistvennye Mashiny, 6: 24-27.

Massantini, F. and G. Magnani (1980). Hydroponic fodder growing: Use of cleaner-separated seed. Fifth International Congress on Soilless Culture.

Mohsenin, NN. (1980). Physical properties of plant and animal materials, New York: Gorden and Breach.

Morgan, J., R.R. Hunter and R. O'Haire (1992). Limiting factors in hydroponic barley grass production. 8th International congress on soil less culture, Hunter's Rest, South Africa, pp: 241-261.

Pandey, H.N. and N.N. Pathak (1991). Nutritional evaluation of artificially grown barley fodder in lactating crossbred cows. Indian Journal of Animal Nutrition, 8(1): 77-78.

Peer, D.J. and S. Leeson (1985a). Feeding value of hydroponically sprouted barley for poultry and pigs. Animal Feed Sci. and Techn., 13: 183-190.

Peer, D.J. and S. Leeson (1985b). Nutrient content of hydroponically sprouted barley. Animal Feed Science and Technology, 13(3-4): 191-202.

SAS (1998). Statistical Analysis Systems. Version 6.11, SAS Institute, Cary, NC.

Singh, K.K. and T.K. Goswam (1996). Physical properties of cumin seed. Journal of Agricultural Engineering Research, 64: 93-98.

Sneath, R. and F. McIntosh (2003). Review of hydroponic fodder production for beef cattle. Project number NBP.332, Department of Primary Industries, PO Box 993, Dalby QLD 4405, Meat \& Livestock Australia Limited, Locked Bag 991, North Sydney NSW 2059. 
Thomas, J.W. and B.S. Reddy (1962). Sprouted oats as a feed for dairy cows. Quarterly Bulletin of the Michigan Agricultural Experiment Station, 44: 654-655.

Trubey, C. R., C. L. Rhykerd, C. H. Noller, D. R. Ford and J. R. George (1969). Effect of light, culture solution, and growth period on growth and chemical composition of hydroponically produced oat seedlings. Agronomy J., 61(5): 663-665.

Urbonavičiūtė, A., G. Samuolienė, S. Sakalauskienė, A. Brazaitytė, J. Jankauskienė, P. Duchovskis, V. Ruzgas, A. Stonkus, P. Vitta, A. Žukauskas and G. Tamulaitis (2009). Effect of flashing chamber light on the nutritional quality of green sprouts. Agronomy Research 7 (Special issue II), 761-767.

\section{الملخص العربى}

تأثثير الإضاءة والتفاعل بين النقع والري ومعدل البذر على إنتاجية علف الشعير



$$
\text { د./ حسين أحمد الصوري1، د. د./عبد الواحد محمد أبوكريمة2 } 3
$$

نظرًا لتز ايد المنافسة بين الحيو ان (أعلاف) وبين الإنسان (غذاء) على الدساحة المحصولية، مما

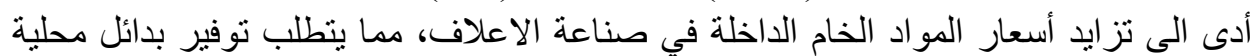



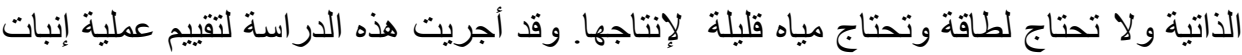

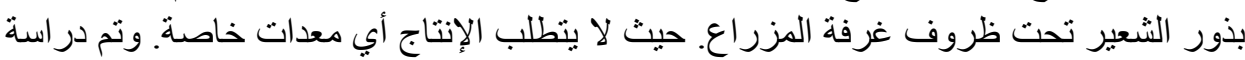

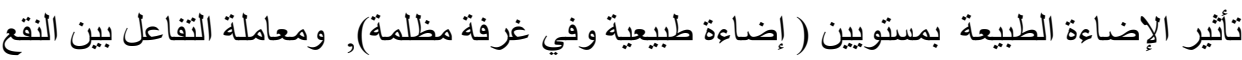

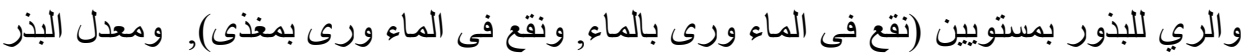

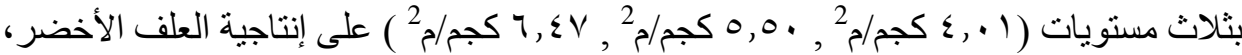

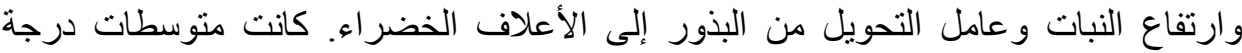

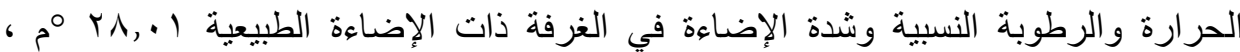
ا

1باحث، معهد بحوث الهندة الزراعية، مركز البحوث الزراعية، مصر

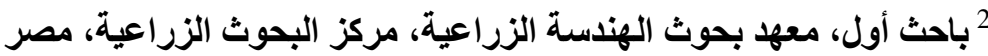

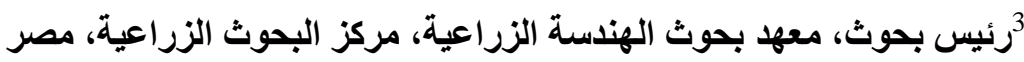




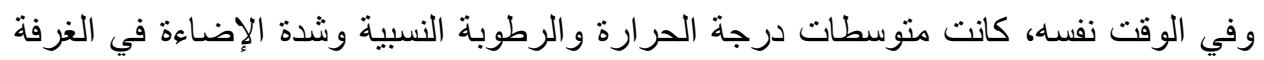

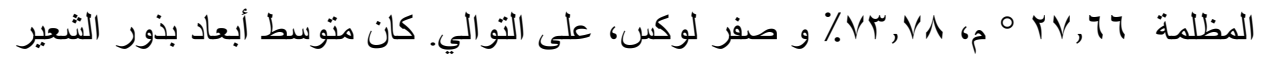

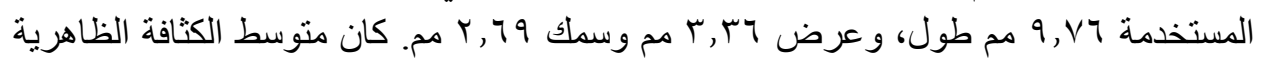

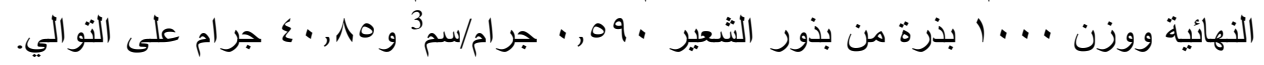

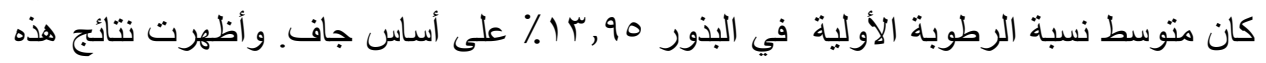

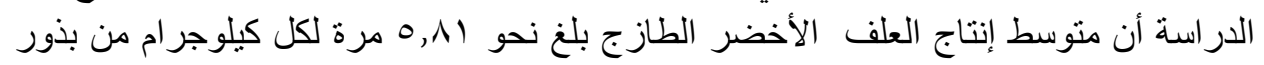

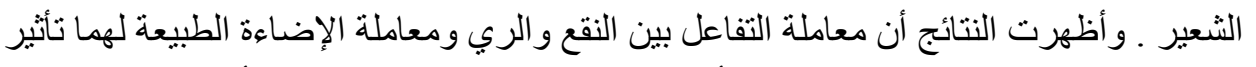

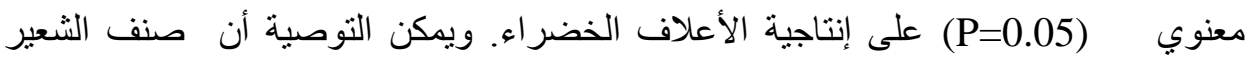

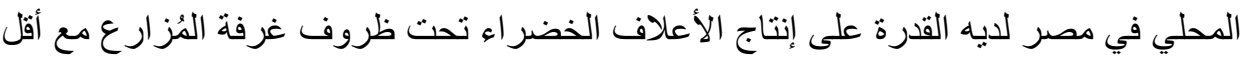

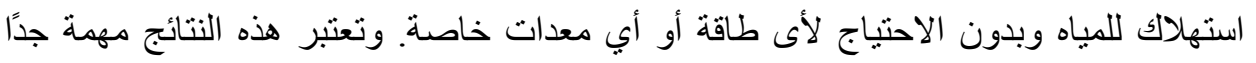

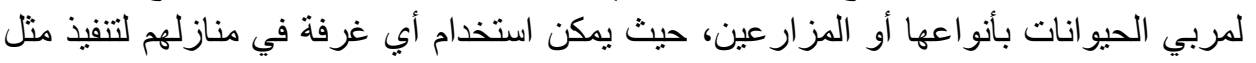

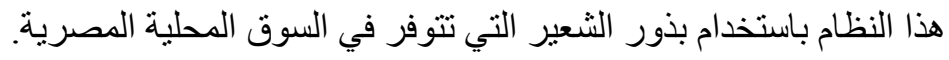

